\title{
"Commercial Demonstration of the Manufactured Aggregate Processing Technology Utilizing Spray Dryer Ash"
}

\author{
Quarterly Technical Progress Report
}

Reporting Period: 11/14/2002 through 12/31/2002

DOE Award No: DE-FC26-02NT41421

Date: June 2003

Submitted by:

Universal Aggregates LLC

300 Bursca Drive

Suite 303

Bridgeville, PA 15017

Roy Scandrol, P.E. 


\section{$\underline{\text { Disclaimer }}$}

"This report was prepared as an account of work sponsored by an agency of the United States Government. Neither the United States Government nor any agency thereof, nor any of their employees makes a warranty, express or implied, or assumed any legal liability or responsibility for the accuracy, completeness, or usefulness of any information, apparatus, product, or process disclosed, or represents that its use would not infringe privately owned rights. Reference herein to any specific commercial product, process, or service by trade name, trademark, manufacturer, or otherwise does not necessarily constitute or imply its endorsement, recommendation, or favoring by the United States Government or any agency thereof. The views and opinions of authors expressed herein do not necessarily state or reflect those of the United States Government or any agency thereof." 


\section{$\underline{\text { Abstract }}$}

This quarterly report covers the period from November $14^{\text {th }}, 2002$ through December $31^{\text {st }}, 2002$. It covers; mix design development, permitting status, engineering status, construction status, and marketing support activities for this period. 


\section{Table of Contents}

\section{$\underline{\text { Page }}$}

Abstract

i

I) Experimental 1

II) Results and Discussion 1

III) Conclusion 2

IV) References 2 
I) Experimental - This section is not applicable to this project.

II) Results and Discussions

This section is broken down into the following subsections: Mix Design, Permitting, Engineering, Construction, and Marketing Support. These subsections describe the activities that have taken place during this quarter as they pertain to this project.

\section{A) Mix Design}

Approximately $700 \mathrm{lb}$ of crushed aggregate with adequate size gradation was produced with the standard Birchwood Power Partners (BPP) mix design including bottom ash addition. The aggregate was used to complete the testing in block production and evaluation by the National Concrete Masonry Association (NCMA) for support of the manufactured aggregate marketing efforts in Virginia and Maryland.

\section{B) Permitting}

The final air permit was received. The well and sanitary system permits are complete. The planning commission approved the site plan. This will allow Universal Aggregates to acquire its building permit. The application for the storm water permit is ready and will be submitted after the first of the year.

\section{C) Engineering}

The layouts for the process building and curing vessel building are in their final form. The single line electrical drawings were modified. Specifications for: Motor Control Center, Low Voltage Devices, Switch Gear, Variable Frequency Drives, Pneumatic Transfer Equipment, Bins and Silos and Conveyors were drafted and comments returned. The preliminary Piping \& Instrument Drawings (P\&IDs) were received and continue to be reviewed with comments returned to R. T. Patterson Company, Inc. (design/engineering firm). Preliminary structural steel and foundation designs have been issued. The Dominion Power letter of authorization to proceed was issued to Dominion Power. Dominion is preparing a cost estimate for the underground feed to the new transformer for the Universal Aggregates plant. Dominion Power is also preparing a right of way document for Birchwood to sign. Bid packages have been prepared for the silos and day bins, pneumatic transfer equipment and conveyors. The curing vessel design was completed and bid package prepared.

\section{D) Construction}

Bids were received for the feeders from four manufacturers. Two declined and two submitted bids. Those bids were reviewed and additional questions have been generated and returned to the manufacturers for clarification prior to selection. The conveyor package and the bins and silo package are out for bids. Those bids are due back near the end of the year. The pneumatic transfer equipment bid package should 
be issued before the end of the year also. The initial curing vessel bids were received and are over our estimate. Additional fabricators were solicited and bids requested.

\section{E) Marketing Support}

Preliminary marketing surveys identified potential customers of lightweight aggregates and potential sales volume within the region (Maryland/Virginia). Initial contact was made with several concrete masonry producers to confirm the survey information and introduce Universal Aggregates LLC as a new lightweight aggregate supplier to the region. Additional communication efforts and meetings with several producers generated sufficient interest to conduct preliminary demonstration testing of concrete masonry while incorporating Universal's "bench - scale", manufactured lightweight aggregate in the producer's standard mix designs, with the companion aggregates typically used in commercial masonry production.

With the assistance of several concrete masonry producers in the market region, Universal Aggregates LLC started preliminary, market introduction testing with the National Concrete Masonry Association in Herndon, Virginia. Engineers and technicians at the National Concrete Masonry Association have been very helpful, and interested in Universal Aggregates material and project.

Communications and contact with potential aggregate customers, and the National Concrete Masonry Association will continue, with efforts to establish sales agreements with those customers.

III) Conclusion - This project is on schedule and within budget. The activities described in section II will continue into the next quarter.

IV) References - Not applicable for this report. 